\title{
Subproduct of the Wine Industry to Replace Forage for Feeding Confined Ovine
}

\author{
Coproduto da Indústria de Vitivinificação como Substituto ao Volumoso na \\ Alimentação de Ovinos Confinados
}

\author{
${ }^{1}$ ÁVILA, Mozer Manneti de \\ https://orcid.org/0000-0001-5812-4688 \\ ${ }^{1}$ MAYENS, Mariane Castro \\ https://orcid.org/0000-0003-0226-4125 \\ ${ }^{1}$ HALFEN, Jéssica \\ https://orcid.org/0000-0002-1317-1322 \\ ${ }^{1}$ BARBOSA, Antônio Amaral \\ https://orcid.org/0000-0001-6062-3486
}

\author{
${ }^{1}$ SILVEIRA, Rutiele \\ https://orcid.org/0000-0003-0522-6095 \\ ${ }^{1}$ FREITAS, Karen Cruz \\ https://orcid.org/0000-0001-9352-3908 \\ ${ }^{1}$ CORRÊA, Marcio Nunes \\ https://orcid.org/0000-0003-0855-2750 \\ ${ }^{1}$ BRAUNER, Cássio Cassal \\ https://orcid.org/0000-0001-5248-2476
}

${ }^{1}$ Universidade Federal de Pelotas -UFPEL, Núcleo de Pesquisa, Ensino e Extensão em Pecuária, Pelotas, RS, Brazil. CORRESPONDENCE: A. A. Barbosa - Campus Universitário, S / N, Capão do Leão - RS, 96160-000.

*Mail for correspondence: 8karenfreitas@gmail.com

\begin{abstract}
The aim of the present study was to evaluate the ingestive behavior of sheep receiving alternative food with grape pomace to replace roughage, as well as its impacts on the rumen environment. It was observed that $\mathrm{BU}$ had higher TOC, TRAM and $\mathrm{pH}$ of the ruminal liquid, while there was less TRU $(\mathrm{P}<0,05)$. As for the other parameters, no significant differences were found. In this study, just as the feeding time was not influenced due to the similarity of the concentrate: roughage ratio in the diet, the protozoan count did not change. This finding reinforces the possibility of using grape marc as a tool for formulating feed, reducing the risk of ruminal disturbances. It was observed that the group control had lower TRAM, indicating that the diet of this group promoted greater microbial activity and, consequently, greater digestibility, corroborating the already observed TOC. This result was the opposite of what was expected, since the grape pomace has probiotic properties, precisely because the fruits have more fungi and bacteria in their microbiota. This also confirms that the co-products of vitiviniculture can act as promoters of the intestinal health of ruminants, justifying further studies in order to improve this use. Therefore, the use of wine by-products is an alternative to reduce production costs, as its use in diets for confined sheep can improve the performance of the animals, increasing the total feed consumption and improving microbial activity.
\end{abstract}

Keywords: behavior; grape pomace; rumination; sustainability. 


\section{RESUMO}

O objetivo do presente estudo foi avaliar o comportamento ingestivo de ovinos recebendo ração alternativa com bagaço de uva em substituição ao volumoso, bem como seus impactos no ambiente ruminal. Observou-se que a BU apresentou maiores COT, TRAM e $\mathrm{pH}$ do líquido ruminal, enquanto houve menor TRU $(\mathrm{P}<0,05)$. Quanto aos demais parâmetros, não foram encontradas diferenças significativas. Neste estudo, assim como o tempo de alimentação não foi influenciado pela similaridade da relação concentrado: volumoso na dieta, a contagem de protozoários não se alterou. Esse achado reforça a possibilidade do uso do bagaço de uva como ferramenta na formulação de rações, reduzindo o risco de distúrbios ruminais. Observou-se que o grupo controle apresentou menor TRAM, indicando que a dieta desse grupo promoveu maior atividade microbiana e, consequentemente, maior digestibilidade, corroborando o COT já observado. Esse resultado foi o oposto do esperado, já que o bagaço de uva tem propriedades probióticas, justamente porque os frutos possuem mais fungos e bactérias em sua microbiota. Isso também confirma que os coprodutos da vitivinicultura podem atuar como promotores da saúde intestinal de ruminantes, justificando novos estudos no sentido de aprimorar esse uso. Portanto, a utilização de subprodutos do vinho é uma alternativa para reduzir os custos de produção, pois seu uso em dietas para ovinos confinados pode melhorar o desempenho dos animais, aumentando o consumo total de ração e melhorando a atividade microbiana.

Palavras-chave: comportamento; bagaço de uva; ruminação; sustentabilidade.

\section{INTRODUCTION}

Brazil is the largest producer of milk, beef and agro-industrial waste in Latin America; responsible for more than 150 tons of residue (ANUNCIAÇÃO, 2017). Buildup of this residue negatively impacts the environment becoming a major hurdle for the sector. Furthermore, transporting this residue to landfills or storing it close to the point of origin without a defined plan to manage it long term are important challenges for this sector.

The residue or subproduct is generated by the food and textile industry. Its utilization in the diet has been researched mainly in ruminants. This research attempts to reduce the cost of food and environmental pollution, preserving natural resources and increasing productivity and environmental efficiency. Therefore, using this residue to feed livestock in regions close to these industries can benefit both the industry and the farmers (AMARAL, 2016).

Among the utilized subproducts, grape pomace has the highest nutritional potential for ruminants due to its high concentration of fiber, protein, oils, condensed tannins and fenolic compounds. These can reduce the methane production in the rumen without negatively impacting productivity (MACIEL, 2012; GRAZZIOTIN 2017). The bromatological composition of grape pomace is 14 to $17 \%$ protein, 44 to $63 \%$ neutral detergent fiber (NDF), $65 \%$ total carbohydrates, 5 to $11 \%$ ether extract and 20 to 23\% lignin (BARROSO, 2006; MENEZES, 2008). Additionally, this 
residue has probiotic features due to its microbial profile (MONTEIRO, 2015). Nevertheless, eating behavior and rumen alterations must be evaluated in order to guarantee that alternate food sources can be used in the diet of ruminants.

Considering this, the present study aimed to evaluate the eating behavior of ovine receiving grape pomace as a replacement for forage and its impact on the ruminal environment.

\section{MATERIALS AND METHODS}

\section{Study Location}

The experiment was conducted at the Núcleo de Pesquisa, Ensino e Extensão em Pecuária (NUPEEC/UFPel), located at the Universidade Federal de Pelotas, between the months of February and March of 2016.

\section{Animals and diet}

Ten Texel and Corriedale mix breed sheep were used. The animals weighed an average $45.7 \mathrm{Kg}$ and were 13 months old. Sheep were identified individually for behavioral evaluation and grouped in stalls per treatment. The facility where the experiment was conducted had covered stalls with rice husk bedding. Sheep were randomly attributed to two groups: control $(\mathrm{CON} ; \mathrm{n}=5)$ and grape pomace (GP; $n=5)$. The control group received a diet containing $39.7 \%$ forage (alfalfa hay), $44.3 \%$ commercial concentrate, and $17 \%$ rice straw. The grape pomace group received a diet containing $25 \%$ grape pomace, $44.3 \%$ commercial concentrate, and 30.63\% forage (alfalfa hay) (Table 1). 
Table 1. Bromatological composition of the diets.

\begin{tabular}{lcc}
\hline Ingredients, g/Kg MS & Control Group & $\begin{array}{c}\text { Grape Pomace } \\
\text { Group }\end{array}$ \\
\hline Alfafa hey & 0,387 & 0,306 \\
Rice Straw & 0,170 & - \\
Concentrate & 0,443 & 0,444 \\
Grape Pomace & - & 0,250 \\
\hline $\begin{array}{l}\text { Bromatological composition, } \\
\text { \% }\end{array}$ & & \\
Ash & 25,89 & 10,85 \\
Ether extract & 1,67 & 2,98 \\
Acid detergent fiber & 26,06 & 27,39 \\
Neutral Detergent fiber & 43,49 & 41,34 \\
Lignin & 5,00 & 12,12 \\
Total digestible nutrients & 55,62 & 55,88 \\
Protein & 16,43 & 16,55 \\
\hline
\end{tabular}

The diets were given daily at 8:30 and 16:30 for a total of 35 days divided in 14 days adaptation and 21 days for sampling. The total amount given per day was calculates according to the amount eaten on the previous days, considering daily leftovers of $10 \%$. The animals received water ad libitum during the entire experimental period, remaining healthy during this period. Evaluation of Ruminal Parameters
Ruminal fluid was obtained using an orogastric probe on days -14 (basal), 1 , 7, 14 and 21 after feeding in the morning. The following tests were carried out immediately after sampling: $\mathrm{pH}$ measurement using a benchtop $\mathrm{pH}$ meter, methylene blue reduction time (MBRT), and sedimentation (DIRKSEN, 1993). A $10 \mathrm{~mL}$ sample was obtained in a sterile tube for posterior 
analysis of protozoa (DEHORITY, 1984).

\section{Evaluation of the eating behavior}

To evaluate the eating behavior, we used a visual approach (FISCHER, 1996), in which each individual animal was observed for 24 hours every 15 minutes and their activities classified as feeding time (FT), rumination time (RT) and resting time (RST). These evaluations were carried out on days $0,3,5,7,9,11$, $13,15,17,19$ e 21 . Day 0 was the last day of feeding adaptation for the animals. Therefore, there was a total of 264 hours of sampling.

\section{Statistical Analysis}

The statistical analysis was carried out using SAS 9.1 $\left(\mathrm{SAS}^{\circledR}\right.$ Institute Inc., Cary, NC, EUA, 2009). Normality of the data was verified by the Shapiro-Wilk test. The data for eating behavior and ruminal parameters were submitted to the PROC MIXED procedure. This was to observe the effects of group and time (days), and their interactions, with statistical significance considered when $P<0,05$. The Qui-square test was used for rectal temperature and respiratory rate, in order to observe the percent of animals within or out of physiologically accepted parameters throughout the experiment. Comparison between averages of the groups was done using the $\mathrm{T}$ test, with statistical significance considered when $P<0,05$.

\section{RESULTS}

In this study, the parameter FT of the eating behavior did not differ between groups $(P=0,071)$. However, RT decreased $(P=0,05)$ and RST increased $(P<0,05)$ for animals supplemented with grape pomace in comparison to the control (Table 2). 
Table 2. Evaluation of the parameters related to the eating behavior such as feeding time (FT) rumination time (RT) and resting time (RST) of ovine supplemented with grape pomace (GP) or not (control)

\begin{tabular}{lccccc}
\hline \multicolumn{2}{c}{ Groups } & \multicolumn{3}{c}{ P value } \\
\hline Parameter & GP & Control & T & $\mathrm{D}$ & $\mathrm{T}^{*} \mathrm{D}$ \\
\hline $\begin{array}{l}\text { FT } \\
\text { (hours/day) }\end{array}$ & 2,51 & 2,78 & 0,071 & $<0,025$ & 0,243 \\
$\begin{array}{l}\text { RT } \\
\text { (hours/day) }\end{array}$ & $5,70^{\mathrm{b}}$ & $6,15^{\mathrm{a}}$ & 0,050 & $<0,001$ & 0,537 \\
$\begin{array}{l}\text { RST } \\
\text { (hours/day) }\end{array}$ & $15,51^{\mathrm{b}}$ & $14,92^{\mathrm{a}}$ & 0,040 & $<0,001$ & 0,322 \\
\end{tabular}

Different letters in the same line indicate a statistical difference $(\mathrm{P}<0,05)$ between groups. $\mathrm{T}$ : comparison of averages between groups; $\mathrm{D}$ : comparison between days; $\mathrm{T}^{*} \mathrm{D}$ : group/day interaction

\section{Ruminal Parameters}

As observed in table 3, the ruminal fluid $\mathrm{pH}$ for animals in the GP group was higher than for animals in the control group $(P=0,045)$. The total protozoa amount $(P=0,18)$ and time to sedimentation did not differ between groups $(P=0,72)$. Additionally, no group-day interaction was observed for the variables tested.

Table 3. Ruminal parameters for ovine supplemented with grape pomace (GP) or not (control)

\begin{tabular}{|c|c|c|c|c|c|}
\hline Parameters & GP & Control & $\mathrm{P}-\mathrm{T}$ & P-D & $\mathrm{P}-\mathrm{T}^{*} \mathrm{D}$ \\
\hline $\mathrm{pH}$ & 7,01 & 6,92 & 0,045 & $<0,001$ & 0,378 \\
\hline Total protozoa $^{1}$ & 970920 & 841220 & 0,181 & $<0,001$ & 0,153 \\
\hline Sedimentation (min) & 6,80 & 6,61 & 0,720 & $<0,001$ & 0,527 \\
\hline
\end{tabular}

${ }^{1}$ number of protozoans $/ \mathrm{mL}$.

$\mathrm{T}$ : comparison of averages between groups; $\mathrm{D}$ : comparison between days; $\mathrm{T}^{*} \mathrm{D}$ : group/day interaction 
For the methylene blue reduction time (MBRT) and interaction was observed between treatment and day with significant reduction in the control group in comparison to the treatment group on days 1 and 7 (Figure 1).

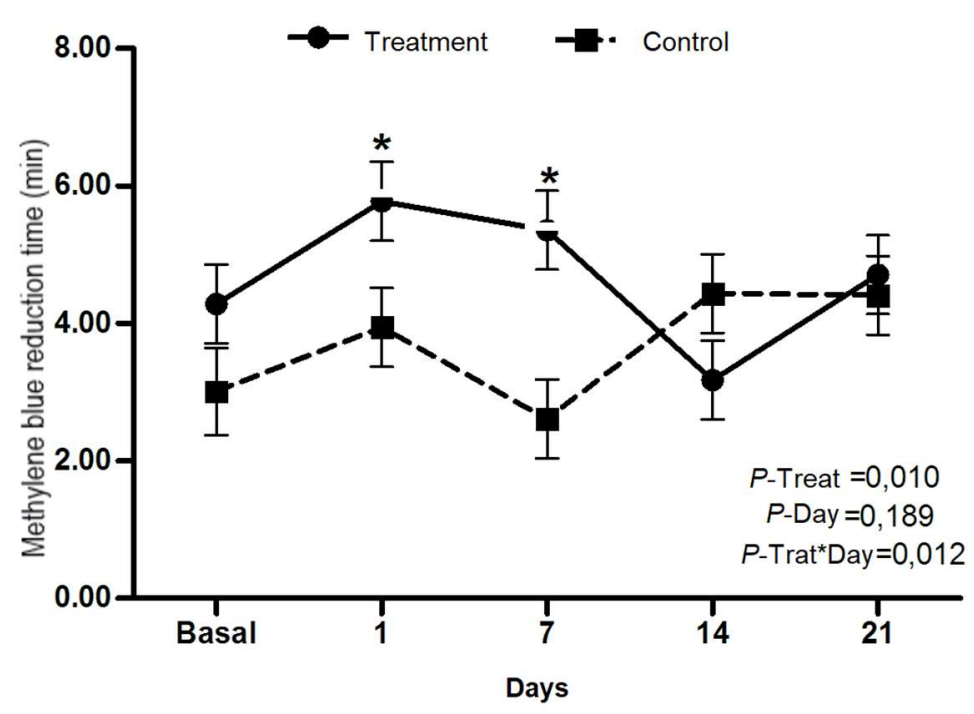

Figure 1. Bacterial reductive activity time

\section{DISCUSSION}

In the present study the eating behavior was similar to that observed in another study (AMARAL, 2019) in which no difference was observed in the amount of food consumed by lambs supplemented or not with grape pomace. On the other hand, a different study found that the food intake increased when alfalfa hay was substituted with grape pomace (KLINGER, 2013). The grape pomace has more lignin which can influence the food intake (JUNIOR, 2005). Nevertheless, these data show that grape pomace can substitute hay without negatively impacting the food intake (FERREIRA, 2007).

The increase observed in rumination time for the animals receiving the control diet $(6,19$ hours/day) in comparison to the treatment group (5,73 hours/day) can be associated with the higher amount of
NDF in the control diet in comparison to control. According to previous studies, increasing the amount of NDF increases the rumination time since more time is required to break the fiber through regurgitation and rumination (FIGUEIREDO, 2013; SANTOS, 2014). Alterations in the time spent on feeding activities have been frequently documented in studies with varied the fiber content in experimental diets (CARVALHO, 2006). Therefore, the NDF content in the control diet can explain the data in this study for resting time which was lower in the control group (approximately $-59 \mathrm{~min} / \mathrm{d}$ ) in comparison to the treatment group. The resting time decreased because of the increase in rumination time (FIGUEIREDO, 2013). Furthermore, the data in this study are consistent with previous data suggesting a linear increase in average feeding time and 
rumination according to the NDF content in the diet (BEUACHEMIN, 1991; DADO, 1995; BURGUER, 2001; PEREIRA, 2018).

The data for eating behavior in this study suggest that the higher the FT and RT the lower the RST (MINERVINO, 2014). The higher RST value in the treatment group can be related to the more easily digestible diet given to this group. Previous data has shown that animals receiving more protein in the diet have higher RST (FIGUEIREDO, 2015). This was observed in this study since the protein content was higher in the treatment group.

The $\mathrm{pH}$ in both groups remained within the physiologically acceptable range of 6,8 to 7,0 (RADOSTITS, 2007; TABELEÃO, 2007), although it was lower in control animals (GUERRARIVAS, 2016). The food that reduces the $\mathrm{pH}$ is usually high starch grain, which are rapidly degraded, and some fruit subproducts due to their naturally low pH (GONZÁLEZ, 2003; OLIVEIRA, 2013). Grapes have a low $\mathrm{pH}$ of 3 after the crushing process, and this can cause reductions in the ruminal $\mathrm{pH}$ (RIZZON, 2002). Even though the rumination time was lowered, these results demonstrate the effective buffering activity of the animal's saliva, which may have helped to maintain the $\mathrm{pH}$ levels constant (GONZÁLEZ, 2003).

The average protozoan concentrations in the ruminal fluid remained within the physiologically accepted range. In general, the protozoa counts vary between $10^{4}$ and $10^{6}$ per $\mathrm{mL}$ of fluid (KAMRA, 2005). This is considered satisfactory since an alteration in the microorganisms can lead to a drop in the digestion rate and nutrient availability (HUNERBERG, 2015). This study differs from other which found a reduction in total protozoa content in animals receiving wine industry residue. The same study reports that discrepancies in the ruminal microbiota are due to the type of diet, the animal and the sampling method (ABARGHUEI, 2010).

Furthermore, the concentrate to forage ratio is inversely proportional to the protozoa content (BURGUER, 2000). In this study, neither FT or protozoa count were altered by the similar amounts of concentrate and forage in the diet. This highlights the potential for using grape pomace in diets with a reduced risk of ruminal disorders.

The sedimentation time was similar between groups and remained within the physiologically accepted values of 4 to 8 minutes (RADOSTITS, 2007). This parameter enables a prompt examination of the ruminal microbiota through the esterification of the components in the ruminal fluid. Reduced values indicate ruminal acidosis (JONES, 2009).

The MBRT analysis indicates the microbial activity in the ruminal fluid (DIRKSEN, 1968). If the microbial activity increases the discoloration of the methylene blue occurs faster. Values between 3 and 6 minutes are considered normal; when values supersede 8 minutes it is considered simple indigestion; and values above 30 minutes are considered acute acidosis (RADOSTITS, 2007). Both groups in this experiment had MBRT values within the physiologically accepted range. However, the control group had lower MBRT values, indicating that the control diet promoted higher microbial activity and digestibility, corroborating the results obtained for RST. 
This result was opposite to the expected considering that grape pomace has probiotic properties (MONTEIRO, 2015), since fruit has more fungus and bacteria in its microbiota (BEUCHAT, 1996; MONTEIRO, 2015). The result also confirms that the subproducts of the wine industry can promote intestinal health, justifying further research to optimize their utilization.

\section{CONCLUSIONS}

Considering the data, we conclude that grape pomace can potentially substitute conventional forage without negatively impacting the ruminal environment. Therefore, grape pomace is a viable alternative that would reduce the costs in livestock production. Furthermore, this study has an invaluable role in optimizing technology for the utilization of grape pomace. This research benefits the livestock industry while providing a sustainable and economic purpose for grape pomace.

\section{REFERENCES}

Abarghuei M.J., Rouzbehan Y. \& Alipour D. 2010. The influence of the grape pomace on the ruminal parameters of sheep. Livestock Science. 132(1): 7379.

Amaral F.P., Grazziotin R.C.B., Machado M.C., Hasse L., Frata M., Blanco C.S., Gonçalves F.M., RibeiroFilho H.M.N., Bermudes R.F., Del Pino F.A.B., Corrêa M.N. \& Brauner C.C. 2019. Limits of grape byproduct inclusion in diets for lambs: Zinc supplementation to prevent copper poisoning. Research in Veterinary Science. 124: 334-337.
Amaral F.P. 2016. Níveis de inclusão do coproduto da vitivinifinicação associado ao zinco na dieta de ovinos. 69f. Pelotas, RS. Dissertação (Mestrado em Zootecnia) - Programa de Pósgraduação em Zootecnia, Universidade Federal de Pelotas.

Anunciação S. 2017. Compostos extraídos do bagaço da uva reduzem processo inflamatório. Campinas: Jornal da Unicamp. Disponível em: $<$ https://www.unicamp.br/unicamp/ju/n oticias/2017/02/20/compostosextraidos-do-bagaco-da-uva-reduzemprocesso-inflamatorio $>$.

Barroso D.D., Araújo G.G.L., Silva D.S. \& Medina F.T. 2006. Resíduo desidratado de vitivinícolas associado a diferentes fontes energéticas na alimentação de ovinos: consumo e digestibilidade aparente. Ciência $e$ Agrotecnologia. 30(4): 767-773.

Beauchemin K.A. 1991. Effects of dietary neutral fiber concentration and alfafa hay quality on chewing, rumen function, and milk production of dairy cows. Journal of Dairy Science. 74(9): 3140-3151.

Beuchat L.R. 1996. Pathogenic microorganisms associated to fresh product. Journal of Food Protection. 59: 204-216.

Bürger P.J., Pereira J.C., Valadares Filho S.C., Silva J.F.C., Queiroz A.C., Cecon P.R. \& Magiero D. 2000. Fermentação ruminal e eficiência microbiana em bezerros holandeses alimentados com dietas contendo diferentes níveis de concentrado. Revista Brasileira de Zootecnia. 29(1): 215-224. 
Carvalho S., Rodrigues M.T., Branco R.H. \& Rodrigues C.A.F. 2006. Comportamento ingestivo de cabras Alpinas em lactação alimentadas com dietas contendo diferentes níveis de fibra em detergente neutro proveniente da forragem. Revista Brasileira de Zootecnia. 35(2): 562-568.

Dado R.G. \&Allen M.S. 1995. Intake limitations, feeding behavior, and rumen function of cows challenged with rumen fill from dietary fiber or inert bulk. Journal of Dairy Science. 78(1): 118133.

Dehority B.A. 1984. Evaluation of subsampling and fixation procedures used for counting rumen Protozoa. Applied Environmental Microbiology. 48: 182-185.

Dirksen D.I. \& Vannevel C.J. 1968. Istdie methylenblau probe als schnelltest fue dir klinishe pansensaft untersuchung gelinet. Deutsche Tierarztliche Wochenschrift. 76: 305-309.

Dirksen G. 1993. Sistema digestivo. In: Rosenberger G. Exame clínico dos bovinos. 3. ed. Rio de Janeiro: Guanabara Koogan, pp. 166-175.

Ferreira W.M., Herrera A.D.P.N., Scapinello C., Fontes D.O., Machado L.C. \& Ferreira S.R.A. 2007. Digestibilidade aparente dos nutrientes de dietas simplificadas baseadas em forrageiras para coelhos em crescimento. Arquivo Brasileiro de Medicina Veterinária e Zootecnia. 59(2): 451-458.

Figueiredo M.R.P., Saliba E.O.S., Borges I., Rebouças G.M.N., Aguiar e Silva F. \& Sá H.C.M. 2013.
Comportamento ingestivo de ovinos alimentados com diferentes fontes de fibra. Arquivo Brasileiro de Medicina Veterinária e Zootecnia. 65(2): 485-489.

Figueiredo M.R.P. 2015. Coprodutos do cacau e do maracujá e indicadores de consumo e digestibilidade aparente em dietas para novilhas leiteiras. 120f. Belo Horizonte, MG. Tese (Doutorado em Zootecnia) - Programa de Pósgraduação em Zootecnia, Universidade Federal de Minas Gerais.

Fischer V. 1996. Efeito do fotoperíodo, da pressão de pastejo e da dieta sobre o comportamento ingestivo de ruminantes. 243f. Porto Alegre, RS. Tese (Doutorado em Zootecnia) - Programa de Pósgraduação em Zootenica, Universidade Federal do Rio Grande do Sul.

González F.H.D. \& Campos R. 2003. Indicadores metabólico-nutricionais do leite. In: González, FH.D., Campos, R. (eds.): Anais do I Simpósio de Patologia Clínica Veterinária da Região Sul do Brasil. Anais do I Simpósio de Patologia Clínica Veterinária da Região Sul do Brasil. Porto Alegre, Gráfica da Universidade Federal do Rio Grande do Sul, pp. 31-47.

Grazziotin R.C.B. 2017. Coproduto da indústria da vitivinificação na dieta de ovinos como estratégia para mitigação do metano entérico. 48f. Pelotas. Dissertação (Mestrado em Ciências) Programa de Pós-graduação em Veterinária, Universidade Federal de Pelotas.

Guerra-Rivas C., Gallardo B., Mantecón A.R., Álamo-Sanza M. \& Manso T. 2016. Evaluation of grape 
pomace from red wine by-product as feed for sheep. Science of Food and Agriculture.95: 1885-1893.

Hünerberg M., McGinn S.M., Beauchemin K.A., Entz T., Harstad O.M. \& McAllister T.A. 2015. Impact of ruminal $\mathrm{pH}$ on enteric methane emissions. Journal of Animal Science. 93: 1760-1766.

Jones S.L. \& Smith B.P. 2009. Diseases of alimentary tract. In: Smith B.P. Large animal internal medicine. 5 ed. Saint Louis: Mosby Elsevier, pp. 638-841.

Junior J.E.L., Neiva J.N.M., Rodriguez N.M., Pimentel J.C.M. \& Lôbo R.N.B. 2005. Consumo e digestibilidade de subprodutos de frutas em ovinos. Revista Brasileira de Zootecnia. 34(2): 659-669.

Kamra D.N. 2005. Rumen microbial ecosystem. Currente Science. 89: 125135.

Klinger A.C.K., Toledo G.S.P., Silva L.P., Maschke F., Chimainski M. \& Siqueira L. 2013. Bagaço de uva como ingrediente alternativo no arraçoamento de coelhos em crescimento. Ciência Rural. 43(9): 1654-1659.

Maciel M.B. 2012. Níveis de inclusão de silagem de bagaço de uva na alimentação de cordeiros em fase de terminação. $96 \mathrm{f}$. Santa Maria. Tese (Doutorado em Zootecnia) - Programa de Pósgraduação em Zootecnia, Universidade Federal de Santa Maria.

Menezes D.R., Araújo G.G.L., Oliveira R.L., Bagaldo A.R. \& Silva T.M. 2008. Ingestão voluntária por ovinos submetidos a rações com coproduto de vitivinícolas desidratado. Revista Brasileira de Saúde e Produção Animal. 9(1): 57-63.

Minervino A.H.H., Araújo C.A.S.C., Kaminishikawahar C.M., Soares F.B., Rodrigues F.A.M.L., Reis L.F., Oliveira F.L.C., Barrêto Júnior R.A., Mori C.S. \& Ortolani E.L. 20014. Influência de diferentes dietas com alto teor de concentrado sobre parâmetros ruminais, bioquímicos e urinários de ovinos. Brazilian Journal of Veterinary Research and Animal Science. 51(1): 3036.

Monteiro A.V., Gonçalves F.M., Pereira R.A., Brustolin J.M., Amaral F.P., Halfen J. \& Corrêa M.N. 2015. Análise microbiológica de coprodutos vitivinícolas com potencial para utilização na alimentação de ruminantes. Science and Animal Health. 3(1): 65-77.

Oliveira V.S, Santana Neto J.A. \& Valença R.L. 2013. Características químicas e fisiológicas da fermentação ruminal de bovinos em pastejo - revisão de literatura. Revista Cientifica Eletrônica de Medicina Veterinária. $\mathrm{XI}(20): 1-21$.

Pereira D.M. 2018. Desempenho e comportamento ingestivo de cordeiros alimentados com dietas contendo níveis de fibra. 52f. João Pessoa. Dissertação (Mestrado em Zootecnia) - Programa de Pós-graduação em Zootecnia, Universidade Federal da Paraíba.

Radostits O.M., Gay C., Hinchcliff K. \& Constable P. 2007. Acute carbohydrate engorgement of ruminants (Ruminal lactic acidosis, rumen 
overload). In: Veterinary Medicine. 10.ed. Londres: Baílliere Tindal, pp.314325 .

Rizzon L.A. \& Miele A. 2002. Acidez na vinificação em tinto das uvas Isabel, Cabernet Sauvignon e Cabernet Franc. Ciência rural. 32(3): 511-515.

Santos N.W., Santos G.T.D., SilvaKazama D.C., Grande P.A., Pintro P.M., Marchi F.E., Jobim C.C. \& Petit H.V. 2014. Production, composition and antioxidants in milk of dairy cows fed diets containing soybean oil and grape residue silage. Livestock Science. 159: $37-45$.

Tabeleão V.C., Del Pino F.A.B., Goulart M.A., Weiser M.A., Schwegler E., Moura S.V., Silva V.M., Roos T.B., Gil-Turnes C., González F.H.D. \& Corrêa M.N. 2007. Caracterização dos parâmetros ruminais e metabólicos de cordeiros mantidos em pastagem nativa. Ciência Animal Brasileira. 8(4): 639-646. 